\title{
Study of Pulmonary Function Tests in Type 2 Diabetes Mellitus: Case Control Study
}

\author{
Dr. Anuradha Yadav $^{1}$, Dr.A.K. Saxena ${ }^{2}$ Dr. Kusum Gaur ${ }^{3}$ \\ Dr.Poonam Punjabi ${ }^{4}$, Dr.Goverdhan Meena ${ }^{5}$ \\ ${ }^{I}$ Associate professor Physiology, S.M.S. Medical College, Jaipur, Rajasthan, India \\ ${ }^{2}$ EX-Professor Physiology, S.M.S. Medical College, Jaipur, Rajasthan, India \\ ${ }^{3}$ Professor PSM, S.M.S. Medical College, Jaipur, Rajasthan, India \\ ${ }^{4}$ Senior Demonstrator, Physiology, S.M.S. Medical College, Jaipur, Rajasthan, India \\ ${ }^{5}$ Associate-Professors, PSM, S.M.S. Medical College, Jaipur, Rajasthan, India
}

\begin{abstract}
Background: Diabetes Mellitus (DM) is a metabolic disorder precipitating micro-vascular, macrovascular complications and peripheral vascular disease. Less has been known about the after effect of diabetes on lungs. So this work was carried out to know the effect of diabetes mellitus on pulmonary functions.

Objective: To find out the effect of diabetes mellitus on pulmonary functions in type $2 \mathrm{DM}$

Material and method: A case-control study was conducted on 30 type 2 DM patients and age sex matched 30 controls after screening both the groups for smoking and acute/chronic pulmonary disease. All subjects underwent screening with detailed history, anthropometry and spirometry at Department of Physiology, SMS medical college, Jaipur. Significance of difference of pulmonary parameters in both the groups was inferred with unpaired ' $t$ ' Test.

Result: Diabetic patients showed highly significant $(P<0.001)$ reduction in almost all the pulmonary parameters. The reduction in pulmonary parameters was not associated with severity and duration of disease.

Conclusion: Diabetic patients showed impaired lung function independent of smoking. Although it was not associated with severity but duration of DM affect FVC and FEV $V_{I}$.
\end{abstract}

Keywords: FEV, FVC, Type 2 diabetes mellitus, Pulmonary function test, Spirometry

\section{INTRODUCTION}

Diabetes mellitus type 2 is a metabolic disorder that is characterized by high blood glucose in the context of insulin resistance and relative insulin deficiency. ${ }^{1}$ This is typically a multi-organ chronic disease and is associated with a ten-year-shorter life expectancy due to its complications. ${ }^{2}$

Globally as of 2010 it was estimated that there were 285 million people with type 2 diabetes making up about $90 \%$ of diabetes cases. ${ }^{2}$ This is equivalent to about $6 \%$ of the world's adult population. ${ }^{3}$ Diabetes is common both in the developed and developing world. ${ }^{4}$

World Health Organization estimates that more than 180 million people worldwide have diabetes, and by 2030 it is expected that this number will have doubled. ${ }^{4}$ There is an alarming increase in the incidence and prevalence of diabetes mellitus (DM) in Asian Indians. ${ }^{5}$

Diabetes has micro-vascular and macro-vascular disorder with debilitating effects on many organs. The alveolar capillary network in the lung is a large micro-vascular unit and may be affected by microangiopathy. ${ }^{6}$ However, because of its large reserve, substantial loss of the micro-vascular bed can be tolerated without developing dyspnoea. As a result, pulmonary diabetic micro-angiopathy usually remains under-recognized clinically.

This study was conducted to measure pulmonary function test (PFT) in type 2 diabetes mellitus subjects and to determine the influence of duration and severity of type 2 diabetes mellitus on pulmonary function test. Hence, we hypothesized that PFTs are affected in DM in Indian population and the changes may correlate with severity and the duration of the disease.

\section{Material And Methods}

A case-control study was conducted on 30 type 2 DM patients and age sex matched 30 controls at Department of Physiology, SMS medical college, Jaipur. Cases were recruited at diabetic clinic, SMS Hospital, Jaipur, who were diagnosed to have type 2 diabetes mellitus by physician according to WHO criteria . ${ }^{7}$ Diabetes is defined when fasting blood glucose $>=126 \mathrm{mg} / \mathrm{dl}$, Mild $-140 \mathrm{mg} / \mathrm{dl}$ to $180 \mathrm{mg} / \mathrm{dl}$, moderate- 180 to $250 \mathrm{mg} / \mathrm{dl}$, severe $>250 \mathrm{mg} / \mathrm{dl}$. These cases were further screened out for smoking and acute/chronic pulmonary disease, any of case should not be smoker or having any acute/chronic pulmonary disease. Extremes of ages were also excluded i.e. $<20$ years and $>60$ Years. 
Age and sex matched non-smoker and free from any acute/chronic pulmonary disease, 30 controls were also identified from the community.

The purpose of the study was explained to the participant and informed consent form was obtained. Then all subjects underwent screening with detailed history, anthropometry and spirometry. Detailed Pulmonary functions tests (PFTs) including FVC, FEV 1 , PEFR, $\mathrm{FEF}_{25-75 \%}, \mathrm{MVV} \& \mathrm{FEV}_{1} / \mathrm{FVC}$ were measured by Medspiror, for 3 times at every 15 minutes interval and best of 3 readings was taken in a quiet room in sitting position, according to American Thoracic Society/European Respiratory Society ATS/ERS guidelines. ${ }^{8,9}$ Medspiror is a computerized spirometer self calibrating, which fulfils the criteria for standardized lung function tests.

Significance of difference of pulmonary parameters in both the groups was inferred with unpaired ' $t$ ' Test. Association of pulmonary function test with diabetic variants were interpreted by one way ANOVA test.

Abbreviations: PFT Pulmonary function tests, DM Diabetes mellitus, FVC forced vital capacity, FEV forced $_{1}$ expiratory volume in $\mathrm{I}^{\text {st }}$ second, PEFR peak expiratory flow rate, $\mathrm{FEF}_{25-75 \%}$ forced expiratory flow during middle half of FVC, MVV maximum voluntary ventilation

\section{Result}

In the present study difference in means of age, sex, BMI, Systolic blood pressure (SBP), Diastolic BP, Serum Cholesterol and Serum Creatinine between cases and controls were not significant $(P<0.05)$, whereas mean Serum glucose levels was found significantly more in cases group.

In this study, among 30 patients 22 had restrictive, 2 had obstructive, 5 mixed blockage and only 1 normal spirometric pattern. (Table 2) Even though Type2 diabetic patients did not have any respiratory symptoms they did have underlying sub clinical restrictive patterns of lung functions.

Regarding pulmonary function defects in the present study, it was observed that normal functioning of lung was found significantly $(\mathrm{P}<0.05)$ more in control group whereas restriction was found significantly $(\mathrm{P}<0.001)$ more in cases group.

Among pulmonary function tests, difference in means of $\mathrm{FVC}, \mathrm{FEV}_{1}$ PEER, $\mathrm{FEF}_{25-75 \%}$, MVV and $\mathrm{FVC} / \mathrm{FEV}$, were found highly significant in both the group in this study. Means of FVC, FEV 1 , PEER, $\mathrm{FEF}_{25-75 \%}$, and MVV were found significantly less whereas $\mathrm{FVC} / \mathrm{FEV}_{1}$ were found significantly more in cases group.

Furthermore, PEER, $\mathrm{FEF}_{25-75 \%}$, MVV, FVC/ $\mathrm{FEV}_{1}$ were not found to be associated with severity and duration of illness whereas $\mathrm{FVC}$ and $\mathrm{FEV}_{1}$ were found to be associated with duration of illness. There was no linear correlation found between PFT and duration of illness where FVC and $\mathrm{FEV}_{1}$ both were found minimum in 15-20 years old DM whereas both of the tests were found maximum in 10-15 years old DM.

\section{Discussion}

Pulmonary function testing has been a major step forward in assessing the functional status of the lungs. ${ }^{10}$ In this study restrictive type of lung function defects were observed in DM type 2 patients, other authors also had reported similar findings ${ }^{11,12}$

Present study showed that all the pulmonary parameters, that is, FVC, FEV $1, \mathrm{FEF}_{25-75}, \mathrm{MVV}$, and PEFR were significantly reduced except FEV ${ }_{1} / \mathrm{FVC}$ in patients of type $2 \mathrm{DM}$ as compared with the healthy controls $(P<0.001)$. The ratio $\mathrm{FEV}{ }_{1} / \mathrm{FVC}$ is greater in diabetic patients $(P>0.05)$. Well comparable findings of reduction in all parameters of PFT in DM type 2, was reported by other authors. ${ }^{13,14} \mathrm{Meo}(2006)^{14}$ observed that lung function parameters like forced vital capacity $(\mathrm{FVC})$, forced expiratory volume in one second $\left(\mathrm{FEV}_{1}\right)$, $\mathrm{FEV}_{1} / \mathrm{FVC}$ ratio, have shown a significant reduction in type 2 diabetes of longer duration. Some authors like Verma et al and Ali et al also reported that there is a significant average reduction in FVC, and $\mathrm{FEV}_{1}$ in type 2 diabetic patients, and it is also demonstrated that peak expiratory flow rate (PEFR) and forced expiratory flow in $25-75 \%\left(\mathrm{FEF}_{25 \%-75 \%}\right)$ may be lower in diabetics, which is inversely related to the duration of the disease. ${ }^{15,16}$ Further more in the present study association not found between PFT and severity of illness and similar findings were observed by other authors. . $^{13,17}$

DM being a systemic disease, which also affects lungs causing restrictive type of ventilatory changes, because of glycosylation of connective tissues, reduced pulmonary elastic recoil and inflammatory changes in lungs. The histopathological changes in the lungs of diabetics are associated with the thickening of the alveolar epithelium and the pulmonary capillary basal lamina and also due to the reduced recoiling of the lung. ${ }^{18}$ This is caused by biochemical alteration of connective tissue constituents, particularly collagen and elastin. There is increased cross-linkage formation between polypeptides of collagen which leads to thickening, leading to restriction of lung volume and alveolar gas transport, reduced membrane diffusion capacity and pulmonary capillary blood volume. . $^{1,20}$ 
Table no.1

Pulmonary Function Defects Comparison of Cases with Controls

\begin{tabular}{|c|c|c|c|c|c|}
\hline \multirow{2}{*}{ S.NO. } & \multirow{2}{*}{ Pulmonary Function Defects } & \multirow{2}{*}{$\begin{array}{c}\text { Cases } \\
\mathbf{N}=\mathbf{3 0}(\mathbf{1 0 0} \%)\end{array}$} & \multirow{2}{*}{$\begin{array}{c}\text { Control } \\
\mathrm{N}=\mathbf{3 0}(\mathbf{1 0 0} \%)\end{array}$} & \multicolumn{2}{|c|}{ Chi-squre Test at 1 DF } \\
\hline & & & & P Value & LS \\
\hline \multirow[t]{2}{*}{1} & \multirow{2}{*}{ Restriction } & \multirow[t]{2}{*}{$22(73.33)$} & \multirow[t]{2}{*}{$2(6.67)$} & \multicolumn{2}{|c|}{25.069} \\
\hline & & & & 0.001 & HS \\
\hline \multirow[t]{2}{*}{2} & \multirow[t]{2}{*}{ Obstruction } & \multirow[t]{2}{*}{$2(6.67)$} & \multirow[t]{2}{*}{$11(36.67)$} & \multicolumn{2}{|c|}{3.889} \\
\hline & & & & 0.049 & $\mathbf{S}$ \\
\hline \multirow[t]{2}{*}{3} & \multirow[t]{2}{*}{ Mixed } & \multirow[t]{2}{*}{$5(16.67)$} & \multirow[t]{2}{*}{$3(10)$} & \multicolumn{2}{|c|}{0.083} \\
\hline & & & & 0.773 & NS \\
\hline \multirow[t]{2}{*}{4} & \multirow[t]{2}{*}{ Normal } & \multirow[t]{2}{*}{$1(3.33)$} & \multirow[t]{2}{*}{$14(46.67)$} & \multicolumn{2}{|c|}{7.591} \\
\hline & & & & 0.006 & $\mathbf{S}$ \\
\hline
\end{tabular}

Table no.2

Pulmonary Function Tests Comparison of Cases with Controls

\begin{tabular}{|c|c|c|c|c|c|}
\hline \multirow[t]{2}{*}{ S.NO. } & \multirow{2}{*}{$\begin{array}{c}\text { Pulmonary Function } \\
\text { Test }\end{array}$} & \multirow{2}{*}{$\begin{array}{l}\text { Cases } \\
\mathbf{N}=\mathbf{3 0}\end{array}$} & \multirow{2}{*}{$\begin{array}{c}\text { Control } \\
\mathbf{N}=\mathbf{3 0}\end{array}$} & \multicolumn{2}{|c|}{ Un-Paired 't' Test (58DF) } \\
\hline & & & & P Value & LS \\
\hline \multirow[t]{2}{*}{1} & \multirow[t]{2}{*}{ FVC } & \multirow[t]{2}{*}{$1.44 \pm 0.51$} & \multirow[t]{2}{*}{$2.81 \pm 0.69$} & \multirow{2}{*}{$0.001^{-8.745}$} & \\
\hline & & & & & HS \\
\hline \multirow[t]{2}{*}{2} & \multirow[t]{2}{*}{ FEV $_{1}$} & \multirow[t]{2}{*}{$1.29 \pm 0.46$} & \multirow[t]{2}{*}{$2.65 \pm 0.73$} & \multirow{2}{*}{$0.001^{-8.633}$} & \\
\hline & & & & & HS \\
\hline \multirow[t]{2}{*}{3} & \multirow[t]{2}{*}{ PEFR } & \multirow[t]{2}{*}{$3.16 \pm 1.62$} & \multirow[t]{2}{*}{$6.57 \pm 2.52$} & \multirow{2}{*}{$0.001^{-6.235}$} & \\
\hline & & & & & HS \\
\hline \multirow[t]{2}{*}{4} & \multirow[t]{2}{*}{ FEF $_{25-75 \%}$} & \multirow[t]{2}{*}{$1.80 \pm 1.03$} & \multirow[t]{2}{*}{$3.89 \pm 1.35$} & \multirow{2}{*}{$0.0011^{-6.741}$} & \\
\hline & & & & & HS \\
\hline \multirow[t]{2}{*}{5} & \multirow[t]{2}{*}{ MVV } & \multirow[t]{2}{*}{$71.03 \pm 25.42$} & \multirow[t]{2}{*}{$112.57 \pm 33.38$} & \multirow{2}{*}{$0.001^{-5.423}$} & \\
\hline & & & & & HS \\
\hline \multirow[t]{2}{*}{6} & \multirow[t]{2}{*}{$\mathrm{FEV}_{1} / \mathrm{FVC}$} & \multirow[t]{2}{*}{$89 \pm 11.39$} & \multirow[t]{2}{*}{$33.83 \pm 8.46$} & \multirow[t]{2}{*}{21.29} & \\
\hline & & & & & HS \\
\hline
\end{tabular}

Table no.3

Association of Pulmonary Function Tests with Diabetes Variants

\begin{tabular}{|c|c|c|c|c|c|c|c|}
\hline \multirow[t]{2}{*}{ S.NO. } & \multirow[t]{2}{*}{ Diabetes Variants } & \multicolumn{6}{|c|}{ Pulmonary Function Tests } \\
\hline & & FVC & FEV $_{1}$ & PEFR & FEF $_{25-75 \%}$ & MVV & $\mathrm{FEV}_{1} / \mathrm{FVC}$ \\
\hline & \multicolumn{4}{|c|}{ Duration of Diabetes } & & & \\
\hline 1 & $<5$ yrs $(\mathrm{N}-4)$ & $1.54 \pm 0.23$ & $1.36 \pm 0.31$ & $3.32 \pm 1.45$ & $1.73 \pm 0.97$ & $87.87 \pm 13.49$ & $69.37 \pm 27.38$ \\
\hline 2 & $5-10$ yrs (N-9) & $1.19 \pm 0.43$ & $1.16 \pm 0.45$ & $2.77 \pm 1.54$ & $2.08 \pm 1.33$ & $96.67 \pm 5.38$ & $69.78 \pm 24.62$ \\
\hline 3 & $10-15$ yrs(N-9) & $1.84 \pm 0.58$ & $1.56 \pm 0.51$ & $3.85 \pm 2.06$ & $1.95 \pm 0.92$ & $84.89 \pm 10.83$ & $82.67 \pm 27.73$ \\
\hline 4 & $15-20$ yrs(N-8) & $0.94 \pm 0.28$ & $0.81 \pm 0.20$ & $2.12 \pm 0.57$ & $0.95 \pm 0.13$ & $89 \pm 16.04$ & $51.00 \pm 3.59$ \\
\hline \multirow[t]{2}{*}{5} & $\begin{array}{l}\text { ANOVA } \\
\text { P Value } \\
\text { LS }\end{array}$ & $\begin{array}{c}\mathrm{F} \quad 6.88 \\
0.001 \\
\text { HS }\end{array}$ & $\begin{array}{c}\mathrm{F} \quad 5.06 \\
0.007 \\
\mathrm{~S}\end{array}$ & $\begin{array}{c}\mathrm{F} \quad 1.91 \\
0.152 \\
\text { NS }\end{array}$ & $\begin{array}{c}\text { F } 2.31 \\
0.100 \\
\text { NS }\end{array}$ & $\begin{array}{c}\mathrm{F} \quad 1.63 \\
0.206 \\
\text { NS }\end{array}$ & $\begin{array}{cc}F \quad 2.78 \\
0.061 \\
\text { NS }\end{array}$ \\
\hline & \multicolumn{4}{|c|}{ Severity Of Diabetes } & & & \\
\hline 1 & Mild (N-7) & $1.63 \pm 0.61$ & $1.40 \pm 0.58$ & $2.55 \pm 1.61$ & $2.11 \pm 1.32$ & $78.28 \pm 32.60$ & $86.14 \pm 16.80$ \\
\hline 2 & Moderate (N-9) & $1.23 \pm 0.39$ & $1.11 \pm 0.34$ & $2.79 \pm 1.20$ & $1.48 \pm 0.80$ & $60.67 \pm 19.13$ & $91.33 \pm 9.68$ \\
\hline 3 & Severe $(\mathrm{N}-14)$ & $1.50 \pm 0.54$ & $1.34 \pm 0.47$ & $3.10 \pm 1.84$ & $1.85 \pm 1.06$ & $74.07 \pm 25.74$ & $90.57 \pm 10.10$ \\
\hline 4 & $\begin{array}{l}\text { ANOVA } \\
\text { P Value } \\
\text { LS }\end{array}$ & $\begin{array}{c}\mathrm{F} \quad 1.30 \\
0.289 \\
\text { NS }\end{array}$ & $\begin{array}{cc}\text { F } & 0.95 \\
0.398 \\
\text { NS }\end{array}$ & $\begin{array}{cc}F & 0.29 \\
0.753 \\
\text { NS }\end{array}$ & $\begin{array}{cc}F & 0.73 \\
0.492 \\
\text { NS }\end{array}$ & $\begin{array}{cc}\text { F } & 1.10 \\
0.347 \\
\text { NS }\end{array}$ & $\begin{array}{cc}\text { F } & 0.44 \\
0.648 \\
\text { NS }\end{array}$ \\
\hline
\end{tabular}

\section{Matching of Cases and Control}

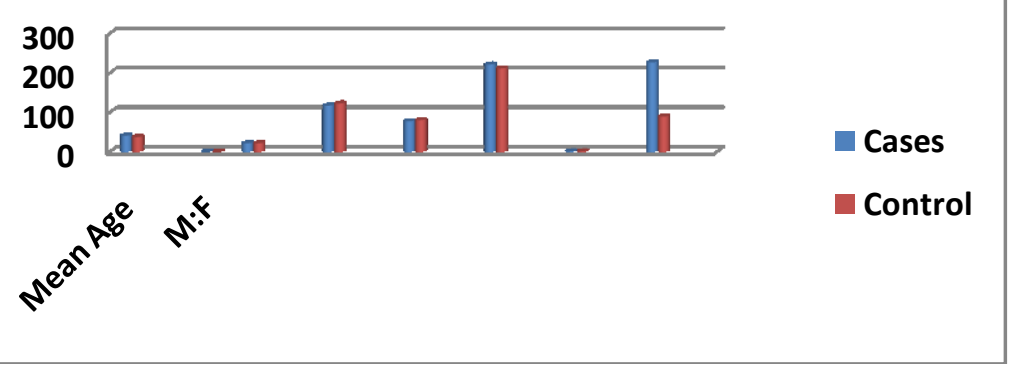




\section{Conclusion}

This study demonstrated that pulmonary function is significantly decreased in type 2 diabetes mellitus, independent of smoking. Reduced lung functions were of particularly restrictive pattern and more in long durational diabetes mellitus. There is a need for periodically assessing the pulmonary function in type 2 diabetes mellitus and spirometry remains a cost effective, a simple non-invasive diagnostic tool and its judicious use can give warning signal for patients to take early preventive measures.

\section{REFERENCES}

[1]. Kumar, Vinay; Fausto, Nelson; Abbas, Abul K.; Cotran, Ramzi S. ; Robbins, Stanley L. (2005). Robbins and Cotran Pathologic Basis of Disease (7th ed.). Philadelphia, Pa.: Saunders. pp. 1194-1195. ISBN 0-7216-0187-1.

[2]. Williams textbook of endocrinology. (12th ed.). Philadelphia: Elsevier/Saunders. pp. 1371-1435. ISBN 978-1-4377-0324-5.

[3]. Meetoo, D; McGovern, P, Safadi, R (2007 Sep 13-27). "An epidemiological overview of diabetes across the world".British journal of nursing (Mark Allen Publishing) 16 (16): 1002-7. PMID 18026039.

[4]. World Health Organization. Fact sheet: Diabetes. No. 312, November 2008 . Available from: http://www.who.int/mediacentre/factsheets/fs312/en/index.html.

[5]. Kings H, Aubert RE, Herman WH. Global burden of diabetes 1995 to 2025. Prevalence, numerical estimates and projections. Diabetes Care 1998;21:1414-31

[6]. Sandler M. Is the lung is target organ in diabetes mellitus? Arch Intern Med 1990;150:1385-8.

[7]. Report of a World Health Organization and International Diabetes Federation meeting 2003 WHO/NMH/MNC/03.1

[8]. American Thoracic Society Statement, Snowbird workshop on standardization of spirometry. Am Rev Respir Dis 1979; 119 : 831-8.

[9]. Miller MR, Hankinson J, Brusasco V, Burgos F, Casaburi R, Coates A, et al. Standardization of spirometry. Eur Respir J 2005;26:319-38.

[10]. Miller M R, Hankinson J, Brusasco V, Burgos F, Casaburi R, Coates A. et al ,Standardisation of spirometry.EurRespir J2005;26:319-38.

[11]. Engstrom GJ, Janzon L. Risk of developing diabetes is inversely related to lung function: A population based cohort study. Diabet Med 2002;19:167-70.

[12]. Yeh HC, Punjabi NM, Wang NY, Pankow J, Duncan BB, Cox CE, et al. Cross sectional and prospective study of lung function in adults with diabetes mellitus. Diabetes 2002;51:A242-3.

[13]. Meo SA, Al-Drees A M,Arif M, Al-Rubean K. Lung function in type 2 Saudi diabetic patients. Saudi Med J 2006;27(3):338-43.

[14]. Agarwal AS, Fuladi AB, Mishra G, Tayade BO. Spirometry and diffusion studies in patients with type 2 diabetes mellitus and their association with microvascular complications. Indian J Chest Dis Allied Sci 2010;52:213-16.

[15]. Verma S, Goni M, Kudyar R P. Assessment of pulmonary functions in patients with diabetes mellitus.JK Science 2009;11(2):71-74.

[16]. Ali M O, Begum S, Begum N, Ali T, Ferdousi S.PEFR and FEF25-75\%in type 2 diabetes mellitus and theirrelationships with its duration.J Bangladesh SocPhysiol2010;5(1):14-19.

[17]. Benbassat CA, Stern E, Kramer M, Lebzelter J, Blum I, Fink G.Pulmonary function in patients with diabetes mellitus. Am J Med Sci $2001 ; 322: 127-32$.

[18]. Kuziemski K, Specjalski K, Jassem E.Diabetic pulmonary microangiopathy - fact or fiction? Pol J Endocr 2011;62:171-75.

[19]. Klein OL, Krishnan JA, Glick S, Smith LJ. Systematic review of the association between lung functionand type 2 diabetes mellitus. Diabet Med 2010;27:977-87.

[20]. Nandhini R, Sayed SS, Saikumar P, Respiratory myopathy in type II diabetes mellitus. JClinDiag Res 2012;6(3):354-57. 